\title{
Lentiform fork sign due to severe metabolic acidosis
}

\author{
Arushi Gahlot Saini, ${ }^{1}$ Sreedeep Kodakkattil Sreevilasan, ${ }^{1}$ Paramjeet Singh, ${ }^{2}$ \\ Pratibha Singhi ${ }^{1}$
}

'Department of Pediatrics, Post Graduate Institute of Medical Education and Research, Chandigarh, India ${ }^{2}$ Department of Radiodiagnosis, Post Graduate Institute of Medical Education and Research, Chandigarh, India

\section{Correspondence to} Professor Pratibha Singhi, doctorpratibhasinghi@gmail. com

Accepted 20 November 2017

\section{DESCRIPTION}

An 11-month-old, developmentally normal, female infant presented with acute-onset fever, vomiting, shallow breathing and gradually progressive lethargy for the past 2 days. There was no history of seizures, neck stiffness, focal motor deficits, cranial nerve palsies, tone changes, rash, diarrhoea, recurrent encephalopathies, abnormal body odour, recurrent infections or hospitalisations, drug or toxin ingestion. Her past and family history was not contributory. On examination, anthropometric parameters were normal for age. She had mild pallor, angular cheilitis, wrist widening, tachypnea (respiratory rate $58 / \mathrm{min}$ ) with acidotic breathing. She was conscious with fluctuations in alertness (Glasgow Coma Scale (GCS) E4M5V2) and irritability with reduced spontaneous activity, mild hypotonia, preserved antigravity movements, brisk muscle stretch reflexes, bilateral extensor plantar response, absence of oculomotor abnormalities, cranial nerve palsies or bulbar signs and normal fundi. Rest of the systemic examination was unremarkable. A clinical diagnosis of acute febrile encephalopathy was considered.

Laboratory investigations showed haemoglobin $85 \mathrm{~g} / \mathrm{L}$, platelets 86000 cells $/ \mu \mathrm{L}$ (range 150000-400000), total leucocyte count 9500 cells $/ \mu \mathrm{L}$ (range 4000-11000) (neutrophils 51\%, lymphocytes 41\%, monocytes $7 \%$ and eosinophils $1 \%$ ), serum sodium $146 \mathrm{meq} / \mathrm{L}$, potassium $4 \mathrm{meq} / \mathrm{L}$, urea $36 \mathrm{mg} / \mathrm{dL}$, creatinine $0.9 \mathrm{mg} /$ $\mathrm{dL}, \mathrm{C}$ reactive protein $56 \mathrm{mg} / \mathrm{dL}$ (normal below $8 \mathrm{mg} / \mathrm{dL}$ ), $\mathrm{B}_{12} 132 \mathrm{pg} / \mathrm{mL}$ (range 211-911), homocysteine $3.86 \mu \mathrm{mol} / \mathrm{L}$ (range 5-15), $\mathrm{pH} 7.21$, serial lactate values 4.5 and $1.4 \mathrm{mmol} / \mathrm{L}$ (normal <2), ammonia $80 \mu \mathrm{mol} / \mathrm{L}$ and normal anion gap. Blood glucose records were normal throughout the hospital stay. Cerebrospinal fluid analysis showed no cells, glucose $149 \mathrm{mg} / \mathrm{dL}$ and protein $152 \mathrm{mg} /$ dL. Blood, urine and cerebrospinal fluid cultures were sterile. MRI of the brain showed bilateral basal ganglia involvement with characteristic lentiform fork sign and a lactate peak on magnetic resonance spectroscopy (figure $1 \mathrm{~A}-\mathrm{E}$ ). Urine analysis did not reveal any reducing substances, methyl malonic acid metabolites, sulfites, glycosaminoglycans or ketones. Tandem mass spectroscopy/gas chromatography was normal. Metabolic acidosis gradually improved with supportive treatment and recovery from febrile illness, and she was discharged after 2 weeks. Follow-up evaluation after 2 months showed mild bradykinesia on neurological examination, and repeat brain MRI revealed remarkable resolution of previously reported lesions.

We describe a case of acute metabolic acidosis associated with acute febrile encephalopathy, bilateral basal ganglia involvement and characteristic lentiform fork sign. The cause for metabolic acidosis was probably recurrent vomiting for the past 2 days associated with poor intake and lethargy. Underlying infection or overwhelming sepsis was also a contributory factor to the initial acidosis. Severe metabolic acidosis, with or without hypoxia and ischaemia, leads to changes in the cerebral microvascular anatomy and blood-brain barrier. These result in vasogenic oedema seen as the bright lentiform fork due to the differential metabolic vulnerability of neurons and astrocytes and may progress to cytotoxic oedema often seen as bilateral

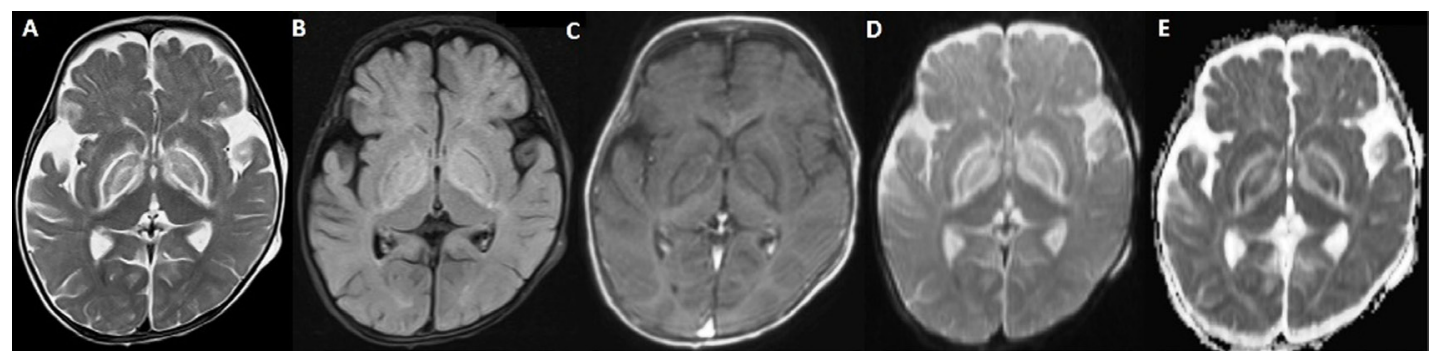

To cite: Saini $A G$, Kodakkattil Sreevilasan S Singh $\mathrm{P}$, et al. BMJ Case Rep Published Online First: [please include Day Month Year]. doi:10.1136/bcr-2017222871
Figure 1 MRI of the brain (A) T2 and (B) FLAIR axial sections showing bilateral hyperintensities in lentiform nuclei (putamen and globus pallidus) and posterior limb of internal capsule with sparing of ventrolateral thalami and the perirolandic white-matter and a brightly hyperintense rim surrounding the globus pallid giving the classic 'fork-like' bright appearance on T2-weighted image. Subtle hyperintensities are also seen in the periventricular and occipital white-matter. These areas are hypointense on FLAIR (B) and (C) non-contrast T1-weighted axial image. (D) Diffusionweighted image shows diffusion restriction in bilateral lentiform nuclei and forks (E) Corresponding apparent diffusion coefficient (ADC) map shows low signal intensity in bilateral lentiform nuclei and high signal intensities of both the forks. Magnetic resonance spectroscopy showed a lactate peak (not shown). The overall MRI picture is consistent with metabolic encephalopathy. 
putaminal necrosis in severe cases. 'Lentiform fork sign' on MRI is a distinctive neuroradiological sign characterised by a bright hyperintense rim delineating the lentiform nucleus as a fork. $^{2}$ It is commonly seen in uremic encephalopathy, diabetes mellitus, methanol and ethylene glycol intoxications, organic acidaemia and pyruvate dehydrogenase deficiency, and underlying metabolic acidosis is the proposed common trigger. In the

\section{Learning points}

Lentiform fork sign on MRI is a distinctive neuroradiological sign.

- Common associated conditions include uremic encephalopathy, diabetes mellitus, methanol and ethylene glycol intoxications, organic acidaemia and pyruvate dehydrogenase deficiency.

- Underlying severe metabolic acidosis, with or without hypoxia and ischaemia, is the common trigger. absence of an underlying systemic disease and life-threatening clinical presentation, the prognosis is generally good as seen in the index case.

Contributors AGS: draft of the manuscript and revision. SKS: draft of the manuscript and revision. PSingh: radiological interpretation of results and revision. PSinghi: clinician in charge, final revision and approval.

Competing interests None declared.

Patient consent Guardian consent obtained.

Provenance and peer review Not commissioned; externally peer reviewed.

(C) BMJ Publishing Group Ltd (unless otherwise stated in the text of the article) 2017. All rights reserved. No commercial use is permitted unless otherwise expressly granted.

\section{REFERENCES}

1 Grasso D, Borreggine C, Perfetto F, et al. Lentiform fork sign: a magnetic resonance finding in a case of acute metabolic acidosis. Neuroradiol I 2014;27:288-92.

2 Kumar G, Goyal MK. Lentiform Fork sign: a unique MRI picture. Is metabolic acidosis responsible? Clin Neurol Neurosurg 2010;112:805-12.

Copyright 2017 BMJ Publishing Group. All rights reserved. For permission to reuse any of this content visit http://group.bmj.com/group/rights-licensing/permissions.

BMJ Case Report Fellows may re-use this article for personal use and teaching without any further permission.

Become a Fellow of BMJ Case Reports today and you can:

- Submit as many cases as you like

- Enjoy fast sympathetic peer review and rapid publication of accepted articles

- Access all the published articles

Re-use any of the published material for personal use and teaching without further permission

For information on Institutional Fellowships contact consortiasales@bmjgroup.com

Visit casereports.bmj.com for more articles like this and to become a Fellow 